\title{
Assessing functional diversity of macrobenthic assemblages in sewage-affected intertidal shores
}

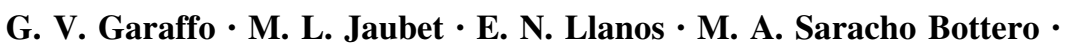 \\ R. Elías
}

Received: 6 September 2018/ Accepted: 14 November 2018/Published online: 22 November 2018

(C) The Author(s) 2018

\begin{abstract}
Functional diversity is the component of diversity that influences ecosystem dynamics, stability, productivity, nutrient balance, and other aspects of ecosystem functioning. We evaluate the spatio-temporal variability of the functional traits (biological traits analysis), functional diversity indices (functional richness, functional evenness, functional divergence and functional dispersion) and AZTI marine biotic index in response to the distinct levels of sewage contamination at different sites on intertidal abrasion platforms. Variations in macrobenthic functional structure between reference and impacted sites were evident in the study area. The functional richness showed a pattern with higher values in the reference sites; Functional evenness showed a similar pattern, but only during spring. Functional divergence presented lower values in the impacted sites during autumn and spring. The functional diversity indices (functional richness and functional evenness) and the AZTI marine biotic index presented a negative relationship, indicating that functional diversity is related to benthic environmental health. Thus, biological traits analysis and functional diversity indices, especially FRic that reveals differences in macrobenthic functional structure between impacted and reference sites during all seasons, represent an informative and useful tool to describe the different aspects of sewage impacts in benthic assemblages on rocky shores. These analyses have a high potential for future monitoring programmes.
\end{abstract}

Keywords Functional traits · Functional diversity $\cdot$ Organic pollution $\cdot$ Benthic health $\cdot$ SW Atlantic

\section{Introduction}

Understanding the processes shaping biological communities under multiple disturbances is a core challenge in ecology and conservation science (Mouillot et al. 2013). Traditional approaches to assess anthropogenic disturbance have usually been focused on taxonomically based structural features, e.g., metrics based on species richness, density/biomass, diversity and environmental quality indices for coastal ecosystems (Borja et al. 2004; Muxika et al. 2007; Muniz et al. 2013). However, these metrics do not consider changes in functional structure, which is central to understand the effects of human disturbances on ecosystem

G. V. Garaffo $(\bowtie) \cdot$ M. L. Jaubet · E. N. Llanos · M. A. S. Bottero · R. Elías

Departamento de Ciencias Marinas, Facultad de Ciencias Exactas y Naturales, Instituto de Investigaciones Marinas y

Costeras (IIMyC), Universidad Nacional de Mar del Plata, Deán Funes 3350, 7602 AYL Mar del Plata, Argentina

e-mail: garaffo@mdp.edu.ar

G. V. Garaffo · M. L. Jaubet · E. N. Llanos · M. A. S. Bottero · R. Elías

Consejo Nacional de Investigaciones Científicas y Técnicas (CONICET), Av. Rivadavia 1917, C1033AAJ Buenos Aires,

Argentina 
functioning (Darr et al. 2014). The functional structure of a community is defined as the distribution of species and their abundances in the functional space (Mouillot et al. 2013).

Functional approach is not a new approach but has recently been popularized as being considered a more meaningful way of analyzing biodiversity compared to the traditional taxonomic analysis (Heino 2008). Functional diversity is the component of diversity that influences ecosystem dynamics, stability, productivity, nutrient balance, and other aspects of ecosystem functioning (Tilman 2001). Many methods and techniques have been proposed to assess the functional diversity of assemblages. The methods most widely used are analysis of biological traits analysis (BTA; Bremner 2008) and calculation of functional diversity indices (Laliberté and Legendre 2010; Villéger et al. 2008). Functional traits (biological characteristics of organisms) are those characteristics that define species in terms of their ecological roles, how they interact with the environment and with other species (Diaz and Cabido 2001). BTA is a multivariate approach that combines information on species distributions over space and time, with the multiple traits (life history, morphological, behavioral) they exhibit (Bremner 2008). On the other hand, the functional diversity indices have varying abilities to reflect the different aspects of assemblage functional trait structure. When the species in an assemblage differ greatly in their functional traits, higher values of these functional diversity indices are expected. Villéger et al. (2008) proposed a framework where functional diversity comprises three independent components: functional richness (FRic), functional evenness (FEve), and functional divergence (FDiv). The three independent components provide more detail in examining the mechanisms linking biodiversity to ecosystem functioning (Casanoves et al. 2008).

FRic represents the trait space filled by a given species assemblage by calculating the convex hull volume that comprises the entire trait space filled by all species of this assemblage (Villéger et al. 2008). The algorithm identifies the extreme species and then estimates the volume in the trait space. This index can thus be used as a proxy of the range of functional traits represented in an assemblage but does not take into account differences in species abundance (Schuldt et al. 2014). FRic is affected by the addition or removal of species with unique trait combinations. FEve index measures the regularity of the abundance distribution in trait space by summing the branch lengths of the minimum spanning tree that is required to connect all species in an assemblage weighted by the species abundances (Villéger et al. 2008). FDiv measures the distribution of the species abundances in relation to the gravity center of the functional trait space (Villéger et al. 2008). So functional divergence is related to how abundance is distributed within the volume of functional traits space (Casanoves et al. 2008). Laliberté and Legendre (2010) proposed the dispersion metric: FDis. It is a multidimensional index based on multitrait dispersion. FDis is the average distance of individual species to the centroid of all species in the community trait space taken into account the relative abundances of species by computing the weighted centroid.

Marine ecosystems are under anthropogenic pressures degrading both biodiversity and functional diversity. Coastal areas in particular are under the influence of multiple disturbances and stressors, naturally or anthropogenically driven, that impact their biodiversity and functioning (Micheli et al. 2016), thereby compromising their ability to sustain ecosystem services (Worm et al. 2006; Halpern et al. 2008). Despite studies with a functional approach have been scarce in marine environments. Francisco and de la Cueva (2017) consider that a more widespread use is urgently needed of this approach.

In aquatic environments, the largest amount of studies related to functional diversity has been developed in riparian macroinvertebrates (Heino 2005, 2008; Heino et al. 2007), as well as in coastal rocky substrate areas (Crowe and Russell 2009; Pacheco et al. 2011) and estuaries (Villéger et al. 2008, 2010; McLenaghan et al. 2011). In particular, in marine benthic environment, studies with functional approach have been proved useful to: (1) assess fishing effects on benthic fauna (e.g., Bremner et al. 2003; Tillin et al. 2006), (2) assess sewage discharges effects on macrobenthic assemblages (Gusmao et al. 2016; Vinagre et al. 2017), (3) investigate the effects of climate change (e.g., Neumann and Kröncke, 2010), (4) use for management and conservation purposes (e.g., Bremner 2008; Frid et al. 2008; Veríssimo et al. 2012), and (5) assess functional diversity in different species assemblages (e.g., Bremner et al. 2003; Hewitt et al. 2008; Van der Linden et al. 2016).

Mar del Plata city has a resident population of about 600,000 people, but receives almost 3,000,000 tourists during summer (December-March and it is placed at the Southwest Atlantic coast of Argentina $\left(38^{\circ} 00^{\prime} \mathrm{S}\right.$, $57^{\circ} 32^{\prime} \mathrm{W}$ ) (Bouvet et al. 2005). The city had the worst scenario for both its environmental status and health of people because raw sewage was directly discharged to intertidal, with a mean flow of $2.8 \mathrm{~m}^{3} \cdot \mathrm{s}^{-1}$ (up to 3.5 $\mathrm{m}^{3} \cdot \mathrm{s}^{-1}$ in summer) (Scagliola et al. 2006). This situation produced $15 \mathrm{~km}$ of beaches unfit for bathing because 
there was a risk for human health (Comino et al. 2010). To date, multiple studies have been conducted in the study area to evaluate the effect of sewage effluent on benthic communities (Elías et al. 2003, 2005, 2006, 2009; Elias et al. 2015; Vallarino and Elías 2006, Vallarino et al. 2014; Jaubet et al. 2011, 2013, 2015; Garaffo et al. 2012, 2016, 2017; Sánchez et al. 2013; Becherucci et al. 2016). However, all these studies had an ecological approach based on taxonomic diversity. The present study proposes to apply for the first time a functional approach and evaluate if this approach is concordant with the AZTI Marine Biotic Index (AMBI). The AMBI was the index that best reflected the environmental quality of the studio area (Garaffo et al. 2017).

From 2015, the sewage pre-treatment plant of Mar del Plata celebrated the setting up of a submarine outfall that moved away the discharge $3.5 \mathrm{~km}$ from coast. Therefore, to have information from both taxonomic and functional approaches of the study area prior to the operation of the submarine outfall will provide a useful background for future studies focusing on the recovery of the resident benthic communities in the area.

The aim of this study was to evaluate the spatial and temporal variability of the functional traits, FD indices and AMBI in response to the distinct levels of sewage contamination at different sites on intertidal abrasion platforms of Mar del Plata, Argentina. We predict that: (a) the functional traits' composition of macrofaunal assemblages varies significantly among impacted and no-impacted sites, (b) lower functional diversity values are expected in contaminated areas and (c) functional diversity indices will be negatively related to AMBI index (higher values of AMBI index indicate bad environmental quality).

\section{Materials and methods}

Study area

The coast of Buenos Aires Province is dominated by sandy beaches; however, around Mar del Plata city $\left(38^{\circ} \mathrm{S}, 57^{\circ} 33^{\prime} \mathrm{W}\right)$, there are quartzite outcrops and almost horizontal intertidal abrasion platforms (geological formation of consolidated loess, limestone, stony rocks or caliche). The tidal regime is semidiurnal with tidal amplitude ranging from approximately $0.8-1.6 \mathrm{~m}$ during exceptional tides. Sea surface temperature shows a great seasonal variation $\left(9.3{ }^{\circ} \mathrm{C}\right.$ in winter and $20^{\circ} \mathrm{C}$ in summer) (Guerrero and Piola 1997), while sea pH remains between 7 and 8.5 (Isla et al. 1998). Until December 2014, the sewage outfall of Mar del Plata city was located $9 \mathrm{~km}$ towards the north of the city center $\left(\mathrm{N}^{\circ} 11\right.$ route, $\mathrm{km}$ 507). This intertidal urban effluent discharged $241,920 \mathrm{~m}^{3}$ of untreated sewage daily during the winter (flow average rate of $2.8 \mathrm{~m}^{3} \mathrm{~s}^{-1}$ ) and $302,400 \mathrm{~m}^{3}$ daily during the summer (average of $3.5 \mathrm{~m}^{3} \mathrm{~s}^{-1}$ ) into the coastal waters (Scagliola et al. 2006), when between two and three million people visit the city (Bouvet et al. 2005).

Sampling design and field and lab routines

Four sampling sites were delimited on intertidal abrasion platforms site 1 (R1), $9000 \mathrm{~m}$ to the north of the outfall; site 2 (R2), $8000 \mathrm{~m}$ to the north; site 3 (I1), $200 \mathrm{~m}$ south of the outfall; and site 4 (I2), $1000 \mathrm{~m}$ to the south (Fig. 1). The sites 3 and 4 are considered impacted by sewage inputs and the sites 1 and 2 are considered as reference locations (Elías et al. 2009; Jaubet et al. 2011, 2013; Sánchez et al. 2013; Garaffo et al. 2016). Sampling was conducted seasonally at each site (February 2008, April 2008, June 2008, November 2008, February 2009, April 2009, June 2009 and November 2009). In each sampling site, 12 sampling units (replicates) were randomly collected from independent rocks using a $10 \mathrm{~cm}$ diameter corer $\left(78 \mathrm{~cm}^{2}\right)$, which was buried into the community matrix up to the basal rocky bottom (up to $20 \mathrm{~cm}$ ). The samples were fixed in $7 \%$ neutralized formalin solution. In the laboratory, each sample was sieved through a $0.5-\mathrm{mm}$ mesh and the retained organisms were identified, counted, and preserved in a $70 \%$ ethanol solution. Environmental variables (turbidity and temperature of the seawater) were measured in situ with a U10 Horiba equipment. The percentage of the total organic matter (TOM) in sediments was determined by the calcinations method (Byers et al. 1978). 


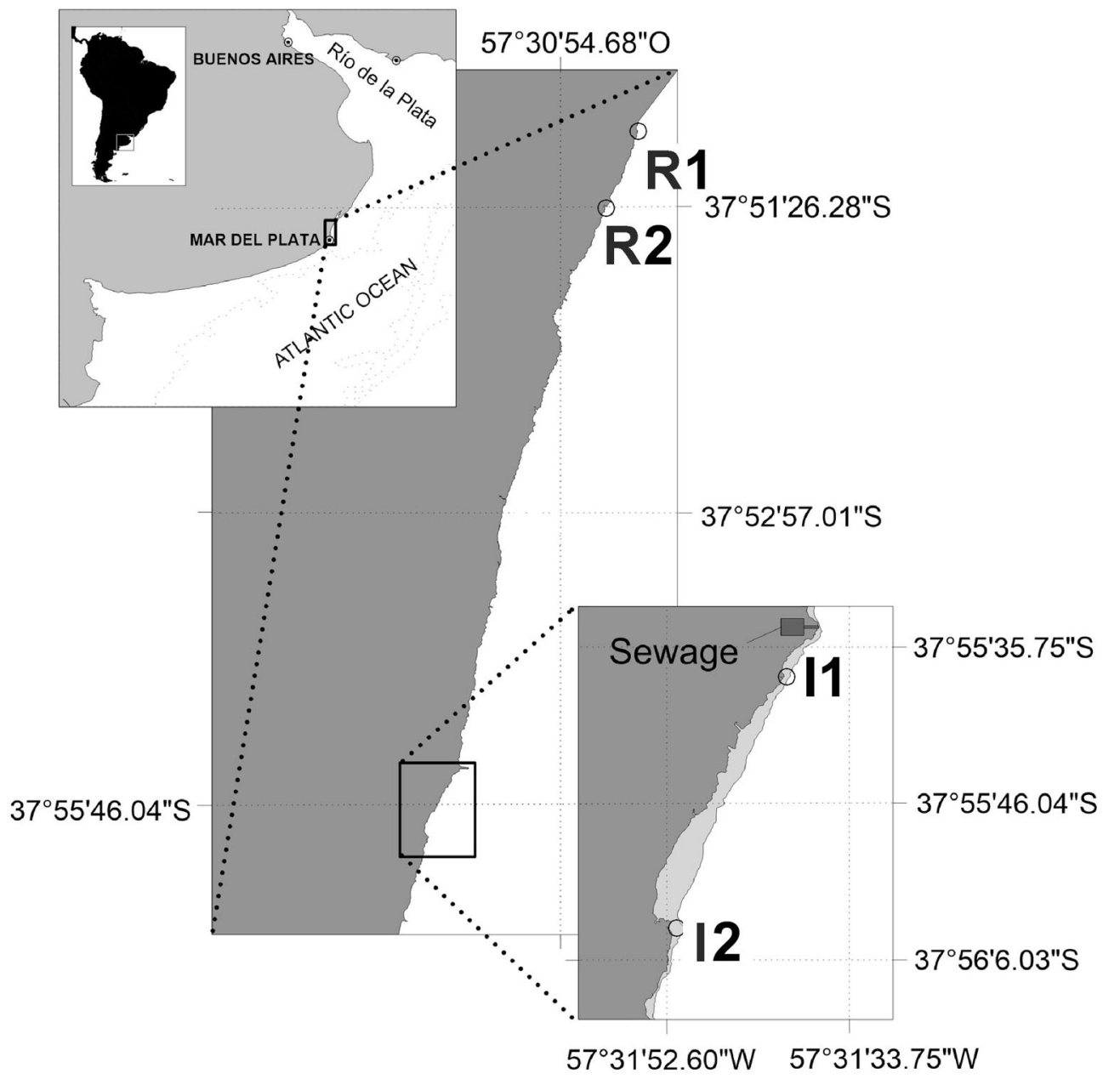

Fig. 1 Distribution of sampling sites (I1, I2, R1 and R2) and intertidal sewage outfall location in the study area. Site I1 was located at $200 \mathrm{~m}$ to the south of the outfall, site $\mathrm{I} 2$ at $1000 \mathrm{~m}$ south, R1 at $9000 \mathrm{~m}$ north and R2 $8000 \mathrm{~m}$ to the north of the outfall

Biological traits analysis

To analyze how the macrofaunal functional trait composition varies among different sites and seasons, we used biological traits analysis (BTA). We chose to use seven functional traits, subdivided into several modalities to represent the range of variation for each functional trait, covering different aspects of the life history, morphology and behavior of each species: depth penetration, maximum size, development mode, living habit, feeding mode, relative adult mobility and tolerance to pollution (Table 1). Rationale for choosing traits was based on the potential of these traits to illustrate changes in ecosystem functioning and responses of benthos to organic pollution. Information on biological traits was gathered from various sources including identification guides (Boschi and Cousseau 2004; Vallarino and Elías 2009), scientific journals and ad hoc information from local specialists. When reliable information was missing, expert judgment and/or data from the nearest phylogenetic neighbor were considered. The "fuzzy coding" procedure (Chevenet et al. 1994), with a scoring ranging from 0 to 3 , was used to classify each taxon according to its association with different modalities of functional traits. No affinity for a trait was coded as 0 and complete affinity as three. The scores for each trait (except for development mode) were assigned considering the species adult form on the shore. Trait scores of each taxon were multiplied by its abundance for every sample and subsequently summed to provide a matrix with the overall frequency of each trait modality per sample. 
Table 1 List of biological traits and respective categories

\begin{tabular}{|c|c|c|}
\hline Biological traits & Trait categories & Labels \\
\hline \multirow[t]{3}{*}{ Depth penetration } & Surface & DS \\
\hline & $0-8 \mathrm{~cm}$ & D0-8 \\
\hline & $>8 \mathrm{~cm}$ & $\mathrm{D}>8$ \\
\hline \multirow[t]{3}{*}{ Maximum size } & Very small $(<1 \mathrm{~cm})$ & SVS \\
\hline & Small $(1-3 \mathrm{~cm})$ & SS \\
\hline & Medium $(>3 \mathrm{~cm})$ & SM \\
\hline \multirow[t]{3}{*}{ Development mode } & Planktotrophic & DP \\
\hline & Lecitotrophic & DL \\
\hline & Direct & DD \\
\hline \multirow[t]{5}{*}{ Feeding mode } & Deposit-feeder & FD \\
\hline & Filter/suspension feeder & $\mathrm{FF}$ \\
\hline & Opportunist/scavenger & FO \\
\hline & Grazer & FG \\
\hline & Predator & FP \\
\hline \multirow[t]{4}{*}{ Living habit } & Burrow dweller & HB \\
\hline & Attached & HA \\
\hline & Tube dweller & HT \\
\hline & Free living & $\mathrm{HF}$ \\
\hline \multirow[t]{4}{*}{ Relative adult mobility } & None & $\mathrm{MN}$ \\
\hline & Low & ML \\
\hline & Medium & MM \\
\hline & High & MH \\
\hline \multirow[t]{5}{*}{ Tolerance to pollution } & 1st order opportunistic & $\mathrm{V}$ \\
\hline & 2nd order opportunistic & IV \\
\hline & Tolerant & III \\
\hline & Indifferent & II \\
\hline & Sensitive & I \\
\hline
\end{tabular}

AMBI and functional diversity metrics

For comparison with the FD indices, AMBI was calculated. The FD indices calculated to assess different components of the functional diversity were: FRic, FEve, FDiv and FDisp. The indices were calculated on the basis of matrix of functional traits with the FDiversity software (Di Rienzo et al. 2008). All taxonomic- and functional-based metrics were calculated per replicate.

Data analysis

The resemblance of the macroinvertebrates assemblages according to site and season was analyzed by PERMANOVA analysis on a Bray-Curtis similarity matrix after a fourth-root transformation [Clarke and Warwick 2001). The design included two fixed factors, "site" (four levels: R1, R2, I1 and I2)] and "season" (summer, autumn, winter and spring). Permutation of residuals under a reduced model (9999 permutations) was selected. The SIMPER (similarity percentage analysis) routine was used to determine the species accounting for the greatest contributions to the dissimilarity between assemblages. Taxa and sites were assessed by a direct gradient analysis of ordination technique (i.e., canonical correspondence analysis, CCA. To determine associations between the data and the main explanatory variables, a biplot from the CCA was obtained by overlaying a vector diagram, based on coefficients from the canonical functions describing each canonical axis, on the ordination graph. The CCA analysis was done using only species or taxa with constancy greater than $10 \%$. Species or taxa with lower constancy are considered occasional. 
Principal components analysis (PCA) was used to analyze the matrix with the overall frequency of each trait modality. This analysis was carried out to explore the relationships among sites and each trait modality. To favor the understanding of generated plot, the sampling units from the same sampling site were averaged.

The spatial and temporal variability for each functional index and AMBI was evaluated using ANOVA model. The design incorporated one spatial scale (sites) and one temporal scale (season). The factors of the linear model were: season (fixed) with four levels and sites (fixed) with four levels with twelve replicates each. Data for 2008 and 2009 were pooled together as replicates of seasons.

The data were combined since they did not show significant differences between years. Variance heterogeneity was analyzed using Cochran test and transformations were applied when necessary. Spearman correlations were used to test the relationship between each index of functional diversity and AMBI.

\section{Results}

Macroinvertebrate assemblages and environmental condition

PERMANOVA showed that the benthic community from impacted sites (I1 and I2) differs significantly from the reference sites (R1 and R2) in all seasons (Pseudo $\mathrm{F}$ site $\times$ season $=7.648, p=0.001$ ). SIMPER analyses showed that the species responsible, up to $90 \%$ of cumulative percentage, of the difference between assemblages of impacted sites and reference sites were Boccardia proboscidea (Polychaete), Brachidontes rodriguezii (Bivalve), Syllis gracilis (Polychaete), Syllis prolixa (Polychaete) and Siphonaria lessonii (Gastropoda). Numerically dominant species in the impacted sites was $B$. proboscidea, while the reference sites were numerically dominated by $B$. rodriguezii (Table 2 ) .

The CCA showed the main environmental variables associated with the occurrence of benthic species and sites. Species were sorted in relation to the first axis, showing a total inertia of 0.589 and explaining $99.3 \%$ of the total variance (eigenvalues for axis 1 was 0.493 ). Axis 1 separated B. proboscidea associated with impacted sites from B. rodriguezii, S. gracilis, S. prolixa and S. lessoni, which were associated with reference sites. Impacted sites showed the highest values of TOM, temperature and turbidity, thus indicating a higher degree of organic pollution than the remaining sites (Fig. 2).

Biological traits analysis

The PCA considering the functional traits displayed eigenvalues of 14.92 and 5.87 for axis 1 and 2, respectively (Fig. 3). The cumulative percentage of variance explained by the first two axes accounted for $86.58 \%$ (62.18\% and $24.4 \%$ for the first and second axis, respectively). A clear separation was observed in assemblage functional trait composition between the impacted and reference sites (axis 1). Assemblage trait composition in the impacted sites was characterized by depth penetration in the sediment between 0 and $8 \mathrm{~cm}$ deep, lecithotrophic and direct development, deposit feeders, burrow dweller and tube dweller living habits, none to low relative mobility and opportunistic species. In the reference sites, an opposite pattern was founded. The separation between the reference sites (axis 2) was influenced mostly by relative adult mobility, tolerance to pollution, living habit and feeding mode. The R1 site (9000 $\mathrm{m}$ to the north of the outfall) was more related to organisms which show high relative mobility and are sensitive (EG I) to pollution. On the other hand, the R2 site ( $8000 \mathrm{~m}$ to the north of the outfall) was more related to organisms which show medium relative mobility, indifferent (EGII) regarding tolerance to pollution, grazer and predator feeding habit and free living habits.

AMBI and functional diversity metrics

The AMBI index values were significantly higher on the impacted sites than reference sites, although there was also variability across sites and season (Table 3, Fig. 4a). The FRic showed significantly higher values on the reference sites than impacted sites; these differences were observed in all seasons except in summer (Table 2, Fig. 4b). The site R1 presented higher FEve values than the rest of the sites during winter and spring. In addition, FEve values showed a greater difference between impacted and reference sites during spring 
Table 2 Pairwise test and SIMPER result showing the taxa contribution to sampling sites dissimilarity according to sampling season (Summer, Autumn, Spring and Winter)

\begin{tabular}{|c|c|c|c|c|c|c|c|c|}
\hline \multicolumn{4}{|l|}{ Pairwise test } & \multicolumn{5}{|l|}{ SIMPER } \\
\hline & Av. Dissim. (\%) & $t$ & $p$ & Taxon & $\begin{array}{l}\text { Av. } \\
\text { Abund. }\end{array}$ & $\begin{array}{l}\text { Av. } \\
\text { Abund. }\end{array}$ & $\begin{array}{l}\text { Contrib. } \\
(\%)\end{array}$ & $\begin{array}{l}\text { Cum. } \\
(\%)\end{array}$ \\
\hline \multicolumn{9}{|l|}{ Summer } \\
\hline \multirow[t]{4}{*}{$\mathrm{R} 1 \neq \mathrm{I} 1$} & 43.66 & 3.3206 & 0.001 & & $\mathrm{R} 1$ & $\mathrm{I} 1$ & & \\
\hline & & & & Boccardia proboscidea & 1.31 & 2.91 & 22.53 & 22.53 \\
\hline & & & & $\begin{array}{l}\text { Brachidontes } \\
\quad \text { rodriguezii }\end{array}$ & 4.93 & 3.28 & 19.62 & 42.15 \\
\hline & & & & Syllis prolixa & 0.89 & 1.09 & 10.30 & 52.45 \\
\hline \multirow[t]{5}{*}{$\mathrm{R} 1 \neq \mathrm{I} 2$} & 35.58 & 3.1085 & 0.001 & & $\mathrm{R} 1$ & $\mathrm{I} 2$ & & \\
\hline & & & & Boccardia proboscidea & 1.31 & 2.95 & 24.25 & 24.25 \\
\hline & & & & Syllis prolixa & 0.89 & 1.56 & 13.57 & 37.83 \\
\hline & & & & $\begin{array}{l}\text { Brachidontes } \\
\quad \text { rodriguezii }\end{array}$ & 4.93 & 3.88 & 13.00 & 50.82 \\
\hline & & & & Lineus bonaerensis & 0.71 & 0.58 & 8.82 & 59.64 \\
\hline $\mathrm{R} 1=\mathrm{R} 2$ & 26.42 & 1.2668 & 0.141 & & & & & \\
\hline \multirow[t]{5}{*}{$\mathrm{I} 1 \neq \mathrm{I} 2$} & 39.95 & 1.8512 & 0.015 & & I1 & $\mathrm{I} 2$ & & \\
\hline & & & & Boccardia proboscidea & 2.91 & 2.95 & 23.55 & 23.55 \\
\hline & & & & Syllis prolixa & 1.09 & 1.56 & 12.86 & 36.41 \\
\hline & & & & $\begin{array}{l}\text { Brachidontes } \\
\quad \text { rodriguezii }\end{array}$ & 3.28 & 3.88 & 10.63 & 47.04 \\
\hline & & & & Siphonaria lessonii & 0.83 & 1.05 & 8.38 & 55.42 \\
\hline \multirow[t]{4}{*}{$\mathrm{I} 1 \neq \mathrm{R} 2$} & 41.87 & 3.0627 & 0.001 & & I1 & $\mathrm{R} 2$ & & \\
\hline & & & & Boccardia proboscidea & 2.91 & 1.81 & 22.44 & 22.44 \\
\hline & & & & $\begin{array}{l}\text { Brachidontes } \\
\quad \text { rodriguezii }\end{array}$ & 3.28 & 4.63 & 16.82 & 39.26 \\
\hline & & & & Syllis prolixa & 0.81 & 1.62 & 10.98 & 50.24 \\
\hline \multirow[t]{5}{*}{$\mathrm{I} 2 \neq \mathrm{R} 2$} & 33.21 & 2.5107 & 0.001 & & $\mathrm{I} 2$ & $\mathrm{R} 2$ & & \\
\hline & & & & Boccardia proboscidea & 2.95 & 1.81 & 24.60 & 24.60 \\
\hline & & & & Syllis prolixa & 1.56 & 0.82 & 14.64 & 39.24 \\
\hline & & & & $\begin{array}{l}\text { Brachidontes } \\
\quad \text { rodriguezii }\end{array}$ & 3.88 & 4.63 & 11.02 & 50.26 \\
\hline & & & & Siphonaria lessonii & 1.05 & 1.48 & 9.53 & 59.80 \\
\hline \multicolumn{9}{|l|}{ Autumn } \\
\hline & & & & & $\mathrm{R} 1$ & $\mathrm{I} 1$ & & \\
\hline $\mathrm{R} 1 \neq \mathrm{I} 1$ & 49.62 & 5.8465 & 0.001 & Boccardia proboscidea & 0.10 & 3.52 & 46.50 & 46.50 \\
\hline \multirow[t]{2}{*}{$\mathrm{R} 1 \neq \mathrm{I} 2$} & 53.27 & 7.6777 & 0.001 & & $\mathrm{R} 1$ & $\mathrm{I} 2$ & & \\
\hline & & & & Boccardia proboscidea & 0.10 & 4.60 & 49.21 & 49.21 \\
\hline \multirow[t]{4}{*}{$\mathrm{R} 1 \neq \mathrm{R} 2$} & 44.98 & 7.9647 & 0.001 & & $\mathrm{R} 1$ & $\mathrm{R} 2$ & & \\
\hline & & & & Boccardia proboscidea & 0.10 & 2.19 & 23.96 & 23.96 \\
\hline & & & & Syllis prolixa & 0.51 & 2.21 & 20.13 & 44.09 \\
\hline & & & & Syllis gracilis & 0.74 & 2.06 & 15.12 & 59.21 \\
\hline $\mathrm{I} 1=\mathrm{I} 2$ & 18.58 & 1.6027 & 0.108 & & & & & \\
\hline \multirow[t]{4}{*}{$\mathrm{I} 1 \neq \mathrm{R} 2$} & 41.43 & 4.0849 & 0.001 & & I1 & $\mathrm{R} 2$ & & \\
\hline & & & & Syllis prolixa & 0 & 2.21 & 23.00 & 23.00 \\
\hline & & & & Syllis gracilis & 0 & 2.06 & 21.54 & 44.54 \\
\hline & & & & Boccardia proboscidea & 3.52 & 2.19 & 15.46 & 60.00 \\
\hline
\end{tabular}


Table 2 continued

\begin{tabular}{|c|c|c|c|c|c|c|c|c|}
\hline \multicolumn{4}{|l|}{ Pairwise test } & \multicolumn{5}{|l|}{ SIMPER } \\
\hline & Av. Dissim. (\%) & $t$ & $p$ & Taxon & $\begin{array}{l}\text { Av. } \\
\text { Abund. }\end{array}$ & $\begin{array}{l}\text { Av. } \\
\text { Abund. }\end{array}$ & $\begin{array}{l}\text { Contrib. } \\
(\%)\end{array}$ & $\begin{array}{l}\text { Cum. } \\
(\%)\end{array}$ \\
\hline \multirow[t]{4}{*}{$\mathrm{I} 2 \neq \mathrm{R} 2$} & 38.02 & 4.439 & 0.001 & & $\mathrm{I} 2$ & $\mathrm{R} 2$ & & \\
\hline & & & & Boccardia proboscidea & 4.60 & 2.19 & 26.06 & 26.06 \\
\hline & & & & Syllis gracilis & 0.46 & 2.06 & 17.14 & 43.20 \\
\hline & & & & $\begin{array}{l}\text { Brachidontes } \\
\text { rodriguezii }\end{array}$ & 3.31 & 4.80 & 15.38 & 58.58 \\
\hline \multirow[t]{4}{*}{$\mathrm{R} 1 \neq \mathrm{I} 1$} & 41.02 & 4.2992 & 0.001 & & $\mathrm{R} 1$ & I1 & & \\
\hline & & & & Boccardia proboscidea & 1.93 & 4.71 & 26.14 & 26.14 \\
\hline & & & & Alitta succinea & 0 & 1.45 & 13.72 & 39.85 \\
\hline & & & & Capitella capitata & 0.18 & 1.39 & 11.86 & 51.71 \\
\hline \multirow[t]{3}{*}{$\mathrm{R} 1 \neq \mathrm{I} 2$} & 47.04 & 2.9543 & 0.001 & & $\mathrm{R} 1$ & $\mathrm{I} 2$ & & \\
\hline & & & & Boccardia proboscidea & 1.93 & 4.14 & 27.52 & 27.52 \\
\hline & & & & $\begin{array}{l}\text { Brachidontes } \\
\quad \text { rodriguezii }\end{array}$ & 3.85 & 2.47 & 20.67 & 48.20 \\
\hline \multirow[t]{5}{*}{$\mathrm{R} 1 \neq \mathrm{R} 2$} & 30.78 & 2.227 & 0.001 & & $\mathrm{R} 1$ & $\mathrm{R} 2$ & & \\
\hline & & & & Boccardia proboscidea & 1.93 & 1.86 & 17.81 & 17.81 \\
\hline & & & & Syllis prolixa & 1.85 & 1.74 & 13.30 & 35.11 \\
\hline & & & & $\begin{array}{l}\text { Brachidontes } \\
\text { rodriguezii }\end{array}$ & 3.85 & 4.72 & 13.26 & 48.38 \\
\hline & & & & Siphonaria lessonii & 0.08 & 0.79 & 11.06 & 59.43 \\
\hline \multirow[t]{5}{*}{$\mathrm{I} 1 \neq \mathrm{I} 2$} & 42.74 & 2.2766 & 0.003 & & $\mathrm{I} 1$ & $\mathrm{I} 2$ & & \\
\hline & & & & $\begin{array}{l}\text { Brachidontes } \\
\quad \text { rodriguezii }\end{array}$ & 3.88 & 2.47 & 16.50 & 16.50 \\
\hline & & & & Boccardia proboscidea & 4.71 & 4.14 & 12.01 & 28.51 \\
\hline & & & & Capitella capitata & 1.39 & 0.17 & 11.50 & 40.01 \\
\hline & & & & Alitta succinea & 1.45 & 0.24 & 11.47 & 51.48 \\
\hline \multirow[t]{5}{*}{$\mathrm{I} 1 \neq \mathrm{R} 2$} & 40.80 & 5.0779 & 0.001 & & I1 & $\mathrm{R} 2$ & & \\
\hline & & & & Boccardia proboscidea & 4.71 & 1.86 & 25.25 & 25.25 \\
\hline & & & & Capitella capitata & 1.39 & 0 & 11.76 & 37.00 \\
\hline & & & & Alitta succinea & 1.45 & 0.29 & 10.59 & 47.60 \\
\hline & & & & $\begin{array}{l}\text { Brachidontes } \\
\quad \text { rodriguezii }\end{array}$ & 3.88 & 4.72 & 7.98 & 55.58 \\
\hline \multirow[t]{4}{*}{$\mathrm{I} 2 \neq \mathrm{R} 2$} & 49.35 & 4.3547 & 0.001 & & $\mathrm{I} 2$ & $\mathrm{R} 2$ & & \\
\hline & & & & Boccardia proboscidea & 4.14 & 1.86 & 24.55 & 24.55 \\
\hline & & & & $\begin{array}{l}\text { Brachidontes } \\
\text { rodriguezii }\end{array}$ & 2.47 & 4.72 & 23.72 & 48.26 \\
\hline & & & & Syllis prolixa & 1.20 & 1.74 & 11.51 & 59.77 \\
\hline \multicolumn{9}{|l|}{ Spring } \\
\hline \multirow[t]{3}{*}{$\mathrm{R} 1 \neq \mathrm{I} 1$} & 63.35 & 6.4388 & 0.001 & & $\mathrm{R} 1$ & $\mathrm{I} 1$ & & \\
\hline & & & & Boccardia proboscidea & 1.72 & 6.05 & 36.28 & 36.28 \\
\hline & & & & $\begin{array}{l}\text { Brachidontes } \\
\text { rodriguezii }\end{array}$ & 4.29 & 1.88 & 23.72 & 60.00 \\
\hline \multirow[t]{3}{*}{$\mathrm{R} 1 \neq \mathrm{I} 2$} & 58.36 & 6.4806 & 0.001 & & $\mathrm{R} 1$ & $\mathrm{I} 2$ & & \\
\hline & & & & Boccardia proboscidea & 1.72 & 5.67 & 35.26 & 35.26 \\
\hline & & & & $\begin{array}{l}\text { Brachidontes } \\
\text { rodriguezii }\end{array}$ & 4.29 & 2.06 & 23.45 & 58.71 \\
\hline
\end{tabular}


Table 2 continued

\begin{tabular}{|c|c|c|c|c|c|c|c|c|}
\hline \multicolumn{4}{|l|}{ Pairwise test } & \multicolumn{5}{|l|}{ SIMPER } \\
\hline & Av. Dissim. (\%) & $t$ & $p$ & Taxon & $\begin{array}{l}\text { Av. } \\
\text { Abund. }\end{array}$ & $\begin{array}{l}\text { Av. } \\
\text { Abund. }\end{array}$ & $\begin{array}{l}\text { Contrib. } \\
(\%)\end{array}$ & $\begin{array}{l}\text { Cum. } \\
(\%)\end{array}$ \\
\hline \multirow[t]{4}{*}{$\mathrm{R} 1 \neq \mathrm{R} 2$} & 34.70 & 2.2146 & 0.002 & & $\mathrm{R} 1$ & $\mathrm{R} 2$ & & \\
\hline & & & & Boccardia proboscidea & 1.72 & 2.61 & 21.90 & 21.90 \\
\hline & & & & Siphonaria lessonii & 1.14 & 0.93 & 15.11 & 37.01 \\
\hline & & & & Syllis gracilis & 0.42 & 1.15 & 13.81 & 50.82 \\
\hline $\mathrm{I} 1=\mathrm{I} 2$ & 37.04 & 0.8395 & 0.461 & & & & & \\
\hline \multirow[t]{3}{*}{$\mathrm{I} 1 \neq \mathrm{R} 2$} & 56.87 & 5.3077 & 0.001 & & I1 & $\mathrm{R} 2$ & & \\
\hline & & & & Boccardia proboscidea & 6.05 & 2.61 & 29.97 & 29.97 \\
\hline & & & & $\begin{array}{l}\text { Brachidontes } \\
\quad \text { rodriguezii }\end{array}$ & 1.88 & 4.32 & 25.06 & 55.03 \\
\hline \multirow[t]{3}{*}{$\mathrm{I} 2 \neq \mathrm{R} 2$} & 51.80 & 5.1702 & 0.001 & & $\mathrm{I} 2$ & $\mathrm{R} 2$ & & \\
\hline & & & & Boccardia proboscidea & 5.67 & 2.61 & 28.83 & 28.83 \\
\hline & & & & $\begin{array}{l}\text { Brachidontes } \\
\text { rodriguezii }\end{array}$ & 2.06 & 4.32 & 25.08 & 53.91 \\
\hline
\end{tabular}

Cumulative percentages that exceed $60 \%$ are not shown

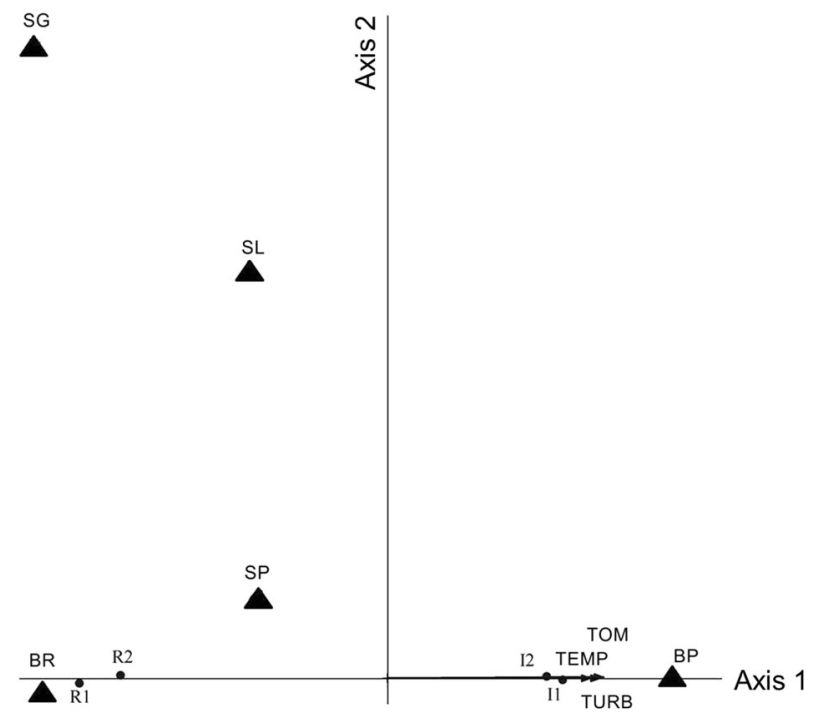

Fig. 2 Ordination diagram of species and sites in the two principal axes of the CCA. The relative lengths of the arrows indicate the importance of a variable. BP Boccardia proboscidea, BR Brachidontes rodriguezii, SP Syllis prolixa, SG Syllis gracilis, SL Siphonaria lessoni, TOM total organic matter, TEMP temperature and TURB turbity. The axis 1 explains $99.3 \%$ of the total variance

(Table 2, Fig. 4c). FDiv presented values with low variability for reference sites across seasons. In contrast, the impacted sites showed variability throughout the seasons. Impacted sites showed a marked decrease in FDiv values during autumn and spring (Table 2, Fig. 4d). The FDis showed significantly higher values on the impacted sites than reference sites during all seasons except for spring (Table 2, Fig. 4e). FRic and FEve were negatively related with the AMBI (EBR) $(p<0.05)(r=-0.250$ and $r=-0.216$, respectively). FDis was positively related with the AMBI. Finally, FDiv showed no significant relationship with AMBI (EBR). 


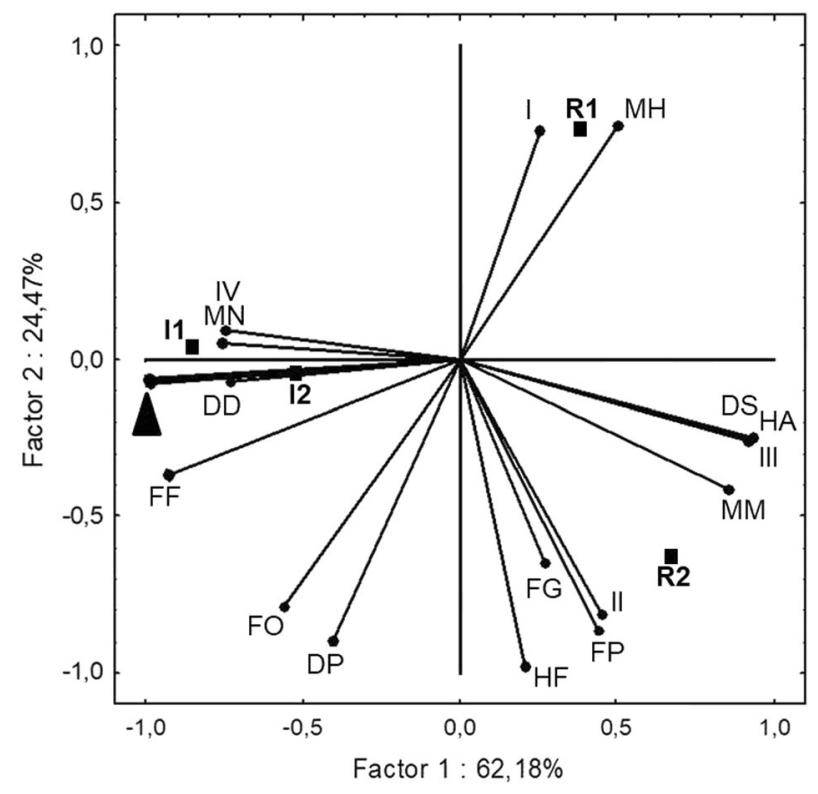

Fig. 3 Principal component analysis (PCA) depicting the trait categories for each site (I1, I2, R1 and R2). Triangle represents the following biological traits: D0-8, D $>8$, DL, FD, HB, HT, ML and V. Traits codes: a depth penetration: DS surface, D0$8=0-8 \mathrm{~cm}, \mathrm{D}>8=>8 \mathrm{~cm}$, b maximum size: $S V S$ very small $(<1 \mathrm{~cm}), S S$ small $(1-3 \mathrm{~cm}), S M$ medium $(>3 \mathrm{~cm})$, c development mode: $D P$ planktotrophic, $D L$ lecitotrophic, $D D$ direct, $\mathbf{d}$ feeding mode: $F D$ deposit-feeder, $F F$ filter/suspension feeder, $F O$ opportunist/scavenger, $F G$ grazer, $F P$ predator, e living habit: $H B$ burrow dweller, $H A$ attached, $H T$ tube dweller, $H F$ free living, f relative adult mobility: $M N$ none, $M L$ low, $M M$ medium, $M H$ high and $\mathbf{g}$ tolerance to pollution: $V 1$ st order opportunistic, IV 2nd order opportunistic, III tolerant, II indifferent and $I$ sensitive

Table 3 Analysis of variance comparing the mean values AMBI index and the four functional diversity indices

\begin{tabular}{lccccrr}
\hline Source & Df & AMBI & FRic & FEve & FDiv & FDis \\
\hline Site $(\mathrm{Si})$ & 3 & $<\mathbf{0 . 0 0 1}$ & $<\mathbf{0 . 0 0 1}$ & $\mathbf{0 . 0 0 1 4}$ & $<\mathbf{0 . 0 0 1}$ & $<\mathbf{0 . 0 0 1}$ \\
Season $(\mathrm{Se})$ & 3 & $<\mathbf{0 . 0 0 1}$ & 0.60 & 0.63 & $<\mathbf{0 . 0 0 1}$ & $\mathbf{0 . 0 1 1}$ \\
$\mathrm{Si} \times \mathrm{Se}$ & 9 & 0.048 & 0.05 & $<\mathbf{0 . 0 0 1}$ & $<\mathbf{0 . 0 0 1}$ & $<\mathbf{0 . 0 0 1}$ \\
\hline
\end{tabular}

The numbers correspond to $p$ values. Bold values indicate the significant results

\section{Discussion}

This is the first time that functional diversity of macrobenthic assemblages (BTA and functional diversity indices) was assessed in sewage-affected rocky shores of the SW Atlantic. To date, the use of functional-based approaches has been widely used in terrestrial and freshwater ecology (Grime 1974; Southwood 1977; Statzner et al. 1994; Charvet et al. 2000; Menezes et al. 2010) and more recently in soft-bottom benthos of transitional and coastal waters (Bremner et al. 2003; Bremner 2005, 2008; Veríssimo et al. 2012; Gusmao et al. 2016; Van der Linden et al. 2016). Only one work has used this approach on rocky shores in the western Portuguese coast (Vinagre et al. 2016).

Variations in functional trait composition between reference and impacted sites were evident in the study area. The index FRic showed a pattern with higher values in the reference sites; FEve showed a similar pattern, but only during spring. FDiv presented lower values in the impacted sites during fall and spring. In addition, the functional diversity indices (FRic and FEve) and AMBI presented a negative relationship, indicating that functional diversity is related to benthic environmental health. Thus, BTAs and functional diversity indices represent an informative and useful tool to describe the different aspects of sewage impacts in benthic assemblages on rocky shores, with high potential for the implementation of monitoring programmes. However, results for functional diversity indices showed more consistent patterns during spring, which indicated that this could be the season better reflecting the disturbance gradients and, therefore, could be the 

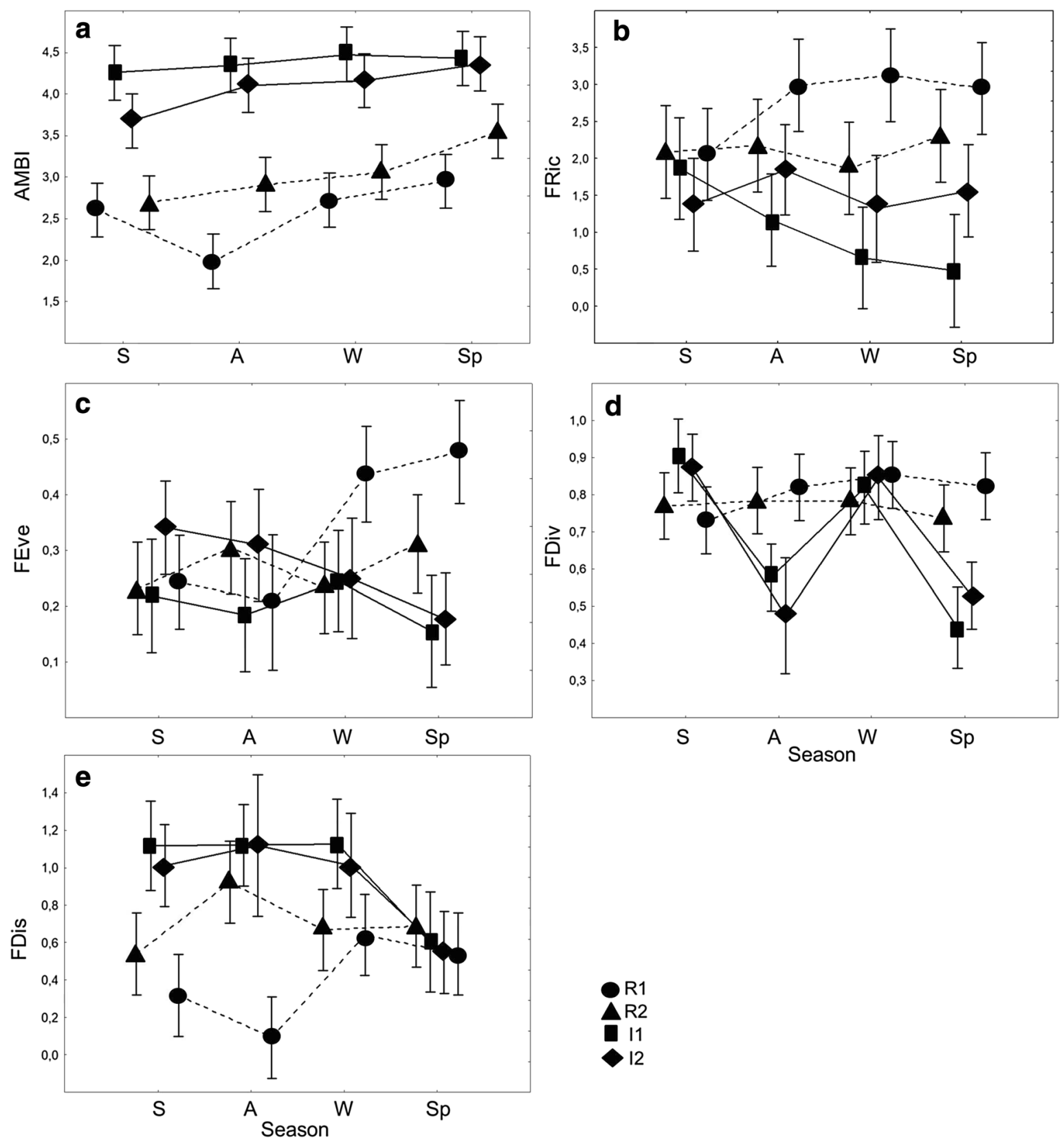

Fig. 4 Mean values ( \pm SE) of AMBI index (a), functional richness (b), functional evenness (c), functional divergence (d) and functional dispersion (e) in each site along seasons

best period to undertake monitoring activities. Also, in other studies more consistent patterns were found in a particular season. Vinagre et al. (2017) concluded that summer could be the best season (compared to winter) to perform monitoring programmes.

BTA allowed the recognition of spatial changes in functioning on rocky shore macroinvertebrate communities within disturbance gradients; therefore, the first prediction was supported. Deposit feeders predominated in the impacted sites. Feeding habit describes the movement of energy and matter through the food web and determines abilities of species to utilize/tolerate different hydrodynamic conditions, e.g., with a switch from predominantly suspension feeders to surface deposit feeders indicating a potential reduction in water movement and siltation (Rosenberg 1995). The dominance of predators and grazer feeders in the reference sites could be related to increased sediment quality, which allows for the establishment of species 
with different feeding habits (Rosenberg 2001). Species with planktotrophic larval development predominated in the reference sites. Different types of recruitment confer different recovery potentials, e.g., communities recruiting mainly by pelagic dispersal are theoretically likely to recover from disturbance more quickly than those with predominantly direct benthic recruitment (Thrush and Whitlatch 2001). In this way, these sites would have a greater chance of recovering from a disturbance and, therefore, be characterized by a higher environmental quality.

Depth penetration in the sediment was between 0 and $8 \mathrm{~cm}$ deep in the impacted sites. This pattern was driven by the dominance of invasive polychaete Boccardia proboscidea in the impacted sites. In non-impacted conditions, the expected pattern is of not depth penetration since there is less amount of sediment to penetrate. The largest amount of sediment appears when Boccardia proboscidea forms the reefs. Finally, the tolerance to pollution (ecological groups: EG) reflects the response of communities to environmental stress (organic enrichment). In this study, the macrofaunal responses to pollution gradients agree with the pattern proposed by Borja et al. (2000).

The use of functional richness (FRic) and functional evenness (FEve) reveal differences in macrobenthic functional structure between impacted and reference sites. The indices FRic (all seasons) and FEve (during spring) showed patterns with higher values in the reference sites. Low functional richness indicates that some of the resources potentially available to the community are unused (Mason et al. 2005) and invasion resistance may also be lower since there will be gaps in niche space which an invader can exploit (Dukes 2001). The results of this study agree with this hypothesis, the impacted sites were dominated by invasive polychaete $B$. proboscidea, which is favored by organic contamination (Jaubet et al. 2011). In the same way, lower functional evenness indicates that some parts of niche space, whilst occupied, are under-utilized. This will tend to decrease productivity and reliability and increase opportunity for invaders (Mason et al. 2005).

With respect to functional divergence, high values of this index indicate a high degree of niche differentiation and thus low resource competition. Thus communities with high functional divergence may have increased ecosystem function as a result of more efficient resource use (Mason et al. 2005). The lowest values of this index were found in impacted sites (during fall and spring); it indicates assemblages with a lower relative abundance of species with extreme/unique categories of functional traits (Gerisch et al. 2012). For FDis index, an opposite pattern to the expected one was found. The lowest values of this index were found in the R1 site, which is furthest from the sewage discharge point. One possible explanation could be that the centroid for the calculation of this index is affected by highly dominant species (Laliberté and Legendre 2010). This site was highly dominated by the ecosystem engineer, the bivalve Brachidontes rodriguezii. According to the above, the second and third predictions were partially supported.

The submarine outfall that moved away the discharge $3.5 \mathrm{~km}$ far from coast was setting up in December2015. This study contributed to a better understanding of the structure and functioning of intertidal rocky shore communities prior to the setting up of a submarine outfall. Future studies focusing on the recovery of the resident communities in the area will improve the knowledge on ecological process associated with marine pollution in the coast of Mar del Plata. The above provides an opportunity to assess whether the functional assemblage structure reflects the changes associated with the recovery of environmental quality. Finally, there seems to be potential to use BTA and the FD indices tested in the present study, together with more traditional methods, in future monitoring progammes to evaluate the evolution of the coast of Mar del Plata.

\section{Conclusions}

Based on the findings of the presented study, it can be concluded that BTAs and functional diversity indices, especially FRic that reveals differences in macrobenthic functional structure between impacted and reference sites during all seasons, represent an informative and useful tool to describe the different aspects of sewage impacts in benthic assemblages on rocky shores, with high potential for the implementation of monitoring programmes. There was a negative relationship between functional diversity indices (FRic and FEve) and the AMBI environmental quality index. This relationship indicates that functional diversity is related to benthic environmental health. Finally, we suggest that functional approach could be implemented in programmes to monitoring the evolution of the coast of Mar del Plata as well as in other coastal areas with similar problems. 
Acknowledgements We are grateful to Dra. MA Sánchez who helped in sampling and sample processing, to Miss MS Rivero who helped in sampling and in the determination of TOM and to Dr. Julio Di Rienzo for helping with the installation FDiversity software. EN Llanos and MA Saracho Bottero were supported by a PhD fellowship from Consejo Nacional de Investigaciones Científicas y Técnicas (CONICET) of Argentina.

Open Access This article is distributed under the terms of the Creative Commons Attribution 4.0 International License (http:// creativecommons.org/licenses/by/4.0/), which permits unrestricted use, distribution, and reproduction in any medium, provided you give appropriate credit to the original author(s) and the source, provide a link to the Creative Commons license, and indicate if changes were made.

\section{References}

Becherucci ME, Llanos EN, Garaffo GV, Vallarino EA (2016) Succession in an intertidal benthic community affected by untreated sewage effluent: a case of study in the SW Atlantic shore. Mar Pollut Bull 109:95-103

Borja A, Franco J, Pérez V (2000) A marine biotic index to establish the ecological quality of soft-bottom benthos within European estuarine and coastal environments. Mar Pollut Bull 40:1100-1114

Borja A, Franco J, Valencia V, Bald J, Muxika I, Belzunce MJ, Solaun O (2004) Implementation of the European water framework directive from the Basque country (northern Spain): a methodological approach. Mar Pollut Bull 48:209-218

Boschi EE, Cousseau MB (2004) La vida entre mareas: vegetales y animales de las costas de Mar del Plata. Publicaciones especiales INIDEP, Mar del Plata, p 383

Bouvet Y, Desse RP, Morell P, Villar MC (2005) Mar del Plata (Argentina): la ciudad balnearia de los porteños en el Atlántico Suroccidental. Investigaciones Geográficas 36:61-80

Bremner J (2005) Assessing ecological functioning in marine benthic communities. University of Newcastle upon, Tyne PhD dissertation

Bremner J (2008) Species' traits and ecological functioning in marine conservation and management. J Exp Mar Biol Ecol 366(1-2):37-47

Bremner J, Rogers SI, Frid CLJ (2003) Assessing functional diversity in marine benthic ecosystems: a comparison of approaches. Mar Ecol Prog Ser 254:11-25

Byers S, Mills C, Stewart P (1978) Comparison of methods of determining organic carbon in marine sediments, with suggestions for a standard method. Hydrobiologia 58(1):43-47

Casanoves F, Di Rienzo JA, Pla L (2008) User manual fdiversity: statistical software for the analysis of functional diversity. First edition, Argentina Link: www.fdiversity.nucleodiversus.org. Accessed July 2017

Charvet S, Statzner B, Usseglio-Polatera P, Dumont B (2000) Traits of benthic macroinvertebrates in semi-natural French streams: an initial application to biomonitoring in Europe. Freshw Biol 43(2):277-296

Chevenet F, Dolédec S, Chessel D (1994) A fuzzy coding approach for the analysis of long-term ecological data. Freshw Biol 31(3):295-309

Clarke KR, Warwick RM (2001) Change in marine communities: an approach to statistical analysis and interpretation, 2nd edn. PRIMER-E, Plymouth

Comino AP, Scagliola M, Ge Z, Frick W (2010) Integrated coastal management strategy of Mar del Plata city and the use of virtual beach as a management tool. In: Proceedings of MWWD 2010, the 6th International Conference on Marine waste water disposal and marine environment (www.mwwd.org), Langkawi, Malaysia, 25-29 October, 2010, p 50-51. Accessed July 2017

Crowe TP, Russell R (2009) Functional and taxonomic perspectives of marine biodiversity: relevance to ecosystem processes. In: Wahl M (ed) Marine hard bottom communities: patterns, dynamics, diversity, change. Elsevier, Amsterdam, pp 375-390

Darr A, Gogina M, Zettler ML (2014) Functional changes in benthic communities along a salinity gradient-a western Baltic case study. J Sea Res 85:315-324

Di Rienzo JA, Casanoves F, Pla L (2008) FDiversity, version 2008. Cordoba, Argentina. www.fdiversity.nucleodiversus.org. Accessed July 2017

Diaz S, Cabido M (2001) Vive la difference: plant functional diversity matters to ecosystem processes. Trends Ecol Evol 16:646-655

Dukes JS (2001) Biodiversity and invasibility in grassland microcosms. Oecologia 126:563-568

Elias R, Jaubet ML, Llanos EN, Sánchez MA, Rivero MS, Garaffo GV, Sandrini-Neto L (2015) Effect of the invader Boccardia proboscidea (polychaeta: Spionidae) on richness, diversity and structure of SW Atlantic epilithic intertidal community. Mar Pollut Bull 91:530-536

Elías R, Rivero MS, Vallarino EA (2003) Sewage impact on the composition and distribution of polychaeta associated to intertidal mussel beds of the Mar del Plata rocky shore, Argentina. Iheringia, Serie Zoología 93(3):309-318

Elías R, Palacios JR, Rivero MS, Vallarino EA (2005) Short-term responses to sewage discharge and storms of subtidal sandbottom macrozoobenthic assemblages off Mar del Plata City, Argentina (SW Atlantic). J Sea Res 53:231-242

Elías R, Rivero, Palacios JR, Vallarino EA (2006) Sewage-induced disturbance on polychaetes inhabiting intertidal mussel beds of Brachidontes rodriguezii off Mar del Plata (Southwestern Atlantic, Argentina). Sci Mar 70(3):187-196

Elías R, Sánchez MA, Jaubet ML, Rivero MS, Vallarino EA (2009) Do treatment sewage plants really work? The intertidal mussels' community of the southwestern Atlantic shore $\left(38^{\circ} \mathrm{S}, 57^{\circ} \mathrm{W}\right)$ as a case study. Rev Biol Mar Oceanogr 44:357-368

Francisco V, de la Cueva H (2017) Nuevas perspectivas en la diversidad funcional de ambientes marinos. Lat Am J Aquat Res 45(2):261-275 
Frid CLJ, Paramor OAL, Brockington S, Bremner J (2008) Incorporating ecological functioning into the designation and management of marine protected areas. Hydrobiologia 606:69-79

Garaffo GV, Jaubet ML, Sánchez MA, Rivero MS, Vallarino EA, Elías R (2012) Sewage induced polychaete reefs in a SW atlantic shore: rapid response to small scale disturbance. Mar Ecol 33:272-279

Garaffo GV, Jaubet ML, Sánchez MA, Llanos EN, Vallarino EA, Elías E (2016) Modelling the influence of environmental and weather factors on the density of the invasive polychaete Boccardia proboscidea. Mar Ecol 37(6):1256-1265

Garaffo GV, Jaubet ML, Becherucci ME, Elías R (2017) Assessing environmental health using ecological indices for soft-bottom in sewage-affected rocky shores: the case of the largest seaside resort of SW Atlantic. Mar Pollut Bull 115:233-239

Gerisch M, Agostinelli V, Henle K, Dziock F (2012) More species, but all do the same: contrasting effects of flood disturbance on ground beetle functional and species diversity. Oikos 121:508-515

Grime JP (1974) Vegetation classification by reference to strategies. Nature 250:26-31

Guerrero RA, Piola AR (1997) Masas de agua en la plataforma continental. In: Boschi EE (ed) El Mar Argentina y sus recursos pesqueros 1. Instituto nacional de investigación y desarrollo pesquero, Mar del Plata, pp 107-118

Gusmao JB, Brauko KM, Eriksson BK, Lana PC (2016) Functional diversity of macrobenthic assemblages decreases in response to sewage discharges. Ecol Indic 66:65-75

Halpern BS, Walbridge S, Selkoe KA, Kappel CV, Micheli F, D’Agrosa C, Bruno JF, Casey KS, Ebert C, Fox HE, Fujita R, Heinemann D, Lenihan HS, Madin EMP, Perry MT, Selig ER, Spalding M, Steneck R, Watson R (2008) A global map of human impact on marine ecosystems. Science 319(5865):948-952

Heino J (2005) Functional biodiversity of macroinvertebrate assemblages along major ecological gradients of boreal headwater streams. Freshw Biol 50:1578-1587

Heino J (2008) Patterns of functional biodiversity and function-environment relationships in lake littoral macroinvertebrates. Limnol Oceanogr 53(4):1446-1455

Heino J, Mykrä H, Kotanen J, Muotka T (2007) Ecological filters and variability in stream macroinvertebrate communities: do taxonomic and functional structure follow the same path? Ecography 30:217-230

Hewitt JE, Thrush SF, Dayton PD (2008) Habitat variation, species diversity and ecological functioning in a marine system. J Exp Mar Bio Ecol 366:116-122

Isla FI, Pérez Guzzi J, Folabella A (1998) Aportes de coliformes a la costa de Mar del Plata (Argentina) por vías naturales e inducidas. Thalassas 14:63-70

Jaubet ML, Sánchez MA, Rivero MS, Garaffo GV, Vallarino EA, Elías R (2011) Intertidal biogenic reefs build by invasive polychaete in sewage-impacted areas of Argentina, SW Atlantic. Mar Ecol 32:1-10

Jaubet ML, Garaffo GV, Sánchez MA, Elías R (2013) Reef-forming polychaetes outcompetes ecosystem engineering mussels. Mar Pollut Bull 71:216-221

Jaubet ML, Garaffo GV, Vallarino EA, Elías R (2015) Invasive polychaete Boccardia proboscidea Hartman, 1940 (polychaeta: spionidae) in sewage-impacted areas of the SW Atlantic coasts: morphological and reproductive patterns. Mar Ecol 36:611-622

Laliberté E, Legendre P (2010) A distance-based framework for measuring functional diversity from multiple traits. Ecology 91:299-305

Mason NWH, Mouillot D, Lee WG, Wilson JB (2005) Functional richness, functional evenness and functional divergence: the primary components of functional diversity. Oikos 111:112-118

McLenaghan NA, Tyler AC, Mahl UH, Howarth RW, Marino RM (2011) Benthic macroinvertebrate functional diversity regulates nutrient and algal dynamics in shallow estuary. Mar Ecol Prog Ser 426:171-184

Menezes S, Baird DJ, Soares AMVM (2010) Beyond taxonomy: a review of macroinvertebrate trait-based community descriptors as tools for freshwater biomonitoring. J Appl Ecol 47(4):711-719

Micheli F, Heiman KW, Kappel CV, Martone RG, Sethi SA, Osio GC, Fraschett S, Shelton AO, Tanner JM (2016) Combined impacts of natural and human disturbances on rocky shore communities. Ocean Coast Manag 126:42-50

Mouillot D, Graham NAJ, Villéger S, Mason NWH, Bellwood DR (2013) A functional approach reveals community responses to disturbances. Trends Ecol Evol 28:167-177

Muniz P, Lana P, Venturini N, Elias, Vallarino E, Bremec C, de Castro Martins C, Sandrini Neto L (2013) Un manual de protocolos para evaluar la contaminación marina por efluentes domésticos p 131 (ISBN: 978-9974-0-0899)

Muxika I, Borja A, Bald J (2007) Using historical data, expert judgement and multivariate analysis in assessing reference conditions and benthic ecological status, according to the European water framework directive. Mar Pollut Bull 55:16-29

Neumann H, Kröncke I (2010) The effect of temperature variability on ecological functioning of epifauna in the German bight. Mar Ecol 32(1):1-9

Pacheco AS, González MT, Bremner J, Oliva M, Heilmayer O, Laudien J, Riascos JM (2011) Functional diversity of marine macrobenthic communities from sub-littoral soft-sediment habitats off northern Chile. Helgol Mar Res 65:413-424

Rosenberg R (1995) Benthic marine fauna structured by hydrodynamic processes and food availability. Neth J Sea Res 34(4):303-317

Rosenberg R (2001) Marine benthic faunal successional stages and related sedimentary activity. Sci Mar 65:107-119

Sánchez MA, Jaubet ML, Garaffo GV, Elías R (2013) Spatial and long-term analyses of reference and sewage-impacted sites in the SW Atlantic $\left(38^{\circ} \mathrm{S}, 57^{\circ} \mathrm{W}\right)$ for the assessment of sensitive and tolerant polychaetes. Mar Pollut Bull 74:325-333

Scagliola M, Furchi P, Von Haeften G, Comino AP, Moschione E, Gonzales R, Gayoso G, Caldararo A, Cerda G, Vergara S, Genga G, Elías R, Vallarino EA (2006) Sewage outfall project of Mar del Plata city (Argentina): an effective intervention to achieve quality objectives on the marine environment. In: Annals of the 4th international conference on marine waste water disposal and marine environment. Antalya, 6-10 November, p 22

Schuldt A, Bruelheide H, Durka W, Michalski SG, Purschke O, Assmann T (2014) Tree diversity promotes functional dissimilarity and maintains functional richness despite species loss in predator assemblages. Oecologia 174:533-543 
Southwood TRE (1977) Habitat, the templet for ecological strategies? J Anim Ecol 46:337-365

Statzner B, Resh VH, Roux LA (1994) The synthesis of long-term ecological research in the context of concurrently developed ecological theory: design of a research strategy for the upper Rhone river and its floodplain. Freshw Biol 31(3):253-263

Thrush SF, Whitlatch RB (2001) Recovery dynamics in benthic communities: balancing detail with simplification. In: Reise K (ed) Ecological comparisons of sedimentary shores, ecological studies. Springer-Verlag, Berlin, pp 297-316

Tillin HM, Hiddink JG, Jennings S, Kaiser MJ (2006) Chronic bottom trawling alters the functional composition of benthic invertebrate communities on a sea-basin scale. Mar Ecol Prog Ser 318:31-45

Tilman D (2001) Functional diversity. In: Levin SA (ed) Encyclopaedia of biodiversity. Academic Press, San Diego, pp 109-120

Vallarino EA, Elías R (2006) High-diverse lowly variable sewage-impacted community, low diverse highly variable natural community: the paradox of the intertidal mussel beds of temperate areas of the SW Atlantic $\left(38^{\circ} \mathrm{S}, 57^{\circ} \mathrm{W}\right)$. Curr Trends Ecol 1:77-91

Vallarino EA, Elías R (2009) La vida en las costas rocosas. Guía de campo. 1ed. Buenos Aires: Dunken 64:pp

Vallarino EA, Garaffo GV, Jaubet ML, Sánchez MA, Rivero MS, Elías R (2014) Are intertidal mussel population's indicators of sewage impact? The response of Brachidontes rodriguezii (Mytilidae) in the South western Atlantic rocky-stony shore. Thalassas 30(1):51-56

Van der Linden P, Marchini A, Dolbeth M, Patrício J, Veríssimo H, Marques JC (2016) The performance of trait-based indices in an estuarine environment. Ecol Indic 61(2):378-389

Veríssimo H, Bremner J, Garcia C, Patrício J, van der Linden P, Marques JC (2012) Assessment of the subtidal macrobenthic community functioning of a temperate estuary following environmental restoration. Ecol Indic 23:312-322

Villéger S, Mason NWH, Mouillot D (2008) New multidimensional functional diversity indices for a multifaceted framework in functional ecology. Ecology 89:2290-2301

Villéger S, Miranda JR, Hernández DF, Mouillot D (2010) Contrasting changes in taxonomic vs. functional diversity of tropical fish communities after habitat degradation. Ecol Appl 20:1512-1522

Vinagre PA, Pais-Costa AJ, Gaspar R, Borja A, Marques JC, Neto JM (2016) Response of macroalgae and macroinvertebrates to anthropogenic disturbance gradients in rocky shores. Ecol Indic 61(2):850-864

Vinagre PA, Veríssimo H, Pais-Costa AJ, Hawkins SJ, Borja A, Marques JC, Magalhães Neto J (2017) Do structural and functional attributes show concordant responses to disturbance? Evidence from rocky shore macroinvertebrate communities. Ecol Indic 75:57-72

Worm B, Barbier EB, Beaumont N, Duffy JE, Folke C, Halpern BS, Jackson JBC, Lotze HK, Micheli F, Palumbi SR, Sala E, Selkoe KA, Stachowicz JJ, Watson R (2006) Impacts of biodiversity loss on ocean ecosystem services. Science 314(5800):787-879

\section{Publisher's Note}

Springer Nature remains neutral with regard to jurisdictional claims in published maps and institutional affiliations. 